\title{
Aristotelism in Czech Structuralism: Jan Mukařovský and Otakar Zich
}

Herta Schmid

\begin{abstract}
The article tries to explain the differences between Zich's and Mukařovský's positions with regard to theory of the dramatic theatre due to their different affinities to the three traditions singled out from ancient Greek metaphysics by Jan Patočka. If Zich follows more the materialistic atomist Democritus, Mukařovský adheres more to Aristotle, whose realism holds the middle between atomism and Plato's idealism. As a result of their different philosophical inclinations, the two Czech structuralists interpret the relation between material and form differently.

The article follows Mukařovskýs gradual development of views focusing on the central ideas in his three main essays: 'Aesthetic Function, Norm and Value as Social Facts' (1936), 'On Poetic Language' (1940), and 'Intentionality and Unintentionality in Art' (1943). The aim of my article is therefore to draw attention to Mukařovskýs study and specifically to his key idea of 'semantic gesture' especially in the dramatic genre in literature as well as in the theatre. In a brief sketch of Euripides' tragedy Medea I try to show how the dramatic dialogue lays bare conflicting ideas about social values in ancient Greek democracy.
\end{abstract}

\section{Key words}

dramatic theatre, material-form debate, principle of correspondence by stylization and deformation, semantic gesture, intrinsic and extrinsic values in Greek tragedy

The paper is an outcome of a research project Divadlo jako syntéza uměni: Otakar Zich v kontextu moderní vědy a dnešní potenciál jeho konceptů / Theatre as Synthesis of Arts: Otakar Zich in Context of Modern Science and Actual Potential of His Concepts (GAČR 2016-2018, GA16-20335S). 
Jan Mukařovský and Otakar Zich have two common fields of interest. One is philosophical aesthetics, the other theatre and literary drama. In his magnum opus under the title The Aesthetics of Dramatic Art: A Theoretical Dramaturgy (1986), originally published in 1931, Zich proclaims that the written drama is no self-standing literary genre as lyrics and epics are, but that it is its destination to enter 'dramatic art' along with several other art-kinds. True dramatic art - so says Zich's credo - takes place only in the theatre. Jan Mukařovský first adhered to Zich's opinion, yet toward the end of the 1930's he changed his mind, proclaiming now that the written drama belongs to the three basic literary genres. Jiří Veltruský supported his professor's new view.

In aesthetics, Mukařovský and Zich come from the tradition of Czech formalism. This tradition originates in the Kantian Johann Friedrich Herbart, who also influenced Russian formalism. With regard to these formalist roots, Mukařovský makes a shift too. In the 1943 article 'Intentionality and Unintentionality in Art' he criticizes Zich's concept of stylization and, at the same time, the Russian formalists' concept of deformation (which can be found already in Herbart's aesthetics). Just like the first, so also the second shift marks a turn in Mukařovskýs own development. Of course, the turn does not mean a total negation of his past, it is rather the result of a revision. The revision culminates in the concept of the semantic gesture (sémantické gesto), which becomes prominent in the studies from 1939 onward, and functions in 1943 as an argument against stylization and deformation.

I shall first try to find an explanation for the remarkable shifts and the turn to the semantic gesture. Thereafter I shall point to a deficit in the structural theory of the drama, which although caused by the concept of semantic gesture might be 'healed' by this same concept. The deficit I bear in mind concerns the components of thought and value in a literary drama.

\section{Mukařovský's critique of Zich's stylization and the formalists' deformation}

In the above-mentioned article of 1943, we find the following reasoning against stylization and deformation: both concepts neglect the role of materiality in art in favour of form. Zich's stylization subdues the total aesthetic structure to an all-embracing formal principal called principal of correspondence. In case of the 'dramatic' art (here and below my quotation marks indicate Zich's definition), correspondence means that all layers of the theatrical performance, beginning at the lowest layer of the actors' bodies on the scene and ending at the highest layer of ideas, undergo forming according to the correlation between action and reaction. As to the formalist deformation, Mukařovský (1970) states that an older form, when having become a general norm, cedes way to a newer form (which might also be a modified very old form). Although in different ways, both stylization and deformation treat the material as a mere passive ground for active form, as Mukařovský has it. On the contrary, the semantic gesture intends an active part of the material vis-à-vis the form imposed upon it. The material 
is no formless mass but has an inherent form. It is true that the imposed artistic form moves the material form to the background, yet even there the effect of the latter must not be totally 'devoured' (žrát).

Given Zich's and the formalists' claim to replace the older form-contents debate in the theory of aesthetics by a new material-form debate, we must take Mukařovský's affront seriously. I will now dare to sketch out with Jan Patočka's help the philosophical traditions of the material-form discussion. Patočka was a co-founder of the Prague Philosophical Circle, which paralleled the Prague Linguistic Circle. The members of these two circles maintained close contact with each other and so did the famous phenomenologist and Aristotelian Patočka.

According to Patočka (1991), there were three metaphysics in ancient Greek philosophy. Plato represented metaphysics from up to down and vice versa. This kind of metaphysical thinking divides the world into an upper sphere of pure ideas and a lower sphere of material bodies. In the human being, a creature wherein spirit and body come together, the spirit strives back to its ideal, bodiless sphere of origin. Democritus is the most prominent thinker of atomistic metaphysics. Atomism dissolves physical bodies into their smallest constituents (atoms) in order to find their laws of combination in the universe and in the natural world. While Platonism and atomism transgress the material world in opposite directions, Aristotle remains in the middle between the poles. He defends the 'naïve' concept of the natural world (also mocked by modern scientists), wherein the human being, as Plato teaches, strives mentally toward the idea, yet at the same time remains in his physical body. The spirit on its way up to idea must never lose touch with the physical body, i.e. the body must never dissolve into the elements of matter. In the centre of Aristotle's philosophy, man stands as a harmonious whole, in which the opposite strives of spirit and body work together.

Aristotle's image of the double striving in man is not entirely given up by Otakar Zich. In The Aesthetics of Dramatic Art, he ultimately aims at the combination of two traditional kinds of aesthetics, the so-called aesthetics from up (ideas) and the aesthetics from down (material). He refers to Johannes Volkelt, who coined these terms. Yet as traditional aesthetics was much more interested in the interpretation of ideas than in the analysis of material and form, Zich tries to work out the lacking analytical tools for the latter. Mukařovský and Veltruský are his followers, but they are discontent with the way Zich links the material basis of the theatrical art with the dramatic text (cf. MUKAǨOVSKÝ 2016; VELTRUSKÝ 2016).

For Zich, the basic material of the theatrical art is the living body of the actor. Bodies in general hold an inherent power. In non-living bodies, that power manifests itself as an inertia, in living bodies as a motive power. This distinction allows classification of the static stage settings on the one side and of the dynamic actors on the other. An actor's dynamics has two aspects. In his resting body, the motive power remains a latent possibility; but when the actor moves, he actualizes the motive power in an energetic movement from one place on the scene to another. Speaking in Zich's terms (see Chapters 6 and 7 in ZICH 1986): when the actor is alone on scene, his sitting or standing body is a potentially dynamic 'power centre'; when he changes places, he actualizes that 
'power centre' in a 'power curve' within the 'power field' of the scene. Between two (or more) actors, the latent dynamics of their bodies create a mutual tension. As soon as the actors move, their bodies describe two (or more) dynamic 'power curves', in which the mutual tensions explode and come again to rest. Zich requires explicitly that there are at least two actors (who, of course, must not continuously be present together), because only the changing relations between two bodies form an action-reaction pattern. That pattern is supposed to pass from the scene to the dialogue and from there to the represented dramatic acts and deeds of protagonist and antagonist.

Mukařovský (2016) felt much impressed by this model of the physical basis of theatre. The model allows indeed better understanding of the avant-gardist material experiments in the time between the two World Wars. In his beginnings, Mukařovský, who soon became the Prague Circle's leading theorist of modern aesthetics, bestowed much more interest in the theatre than in literary drama. Where, then, does he see the problematic of stylization?

As far as I can see, the problems come afore in Zich's opinion about the effects of the visual body and the audible speech on the audience in the theatre. According to Zich (1986: 100), visual movements perceived by the eye have a much stronger impact on the human being than audible sounds perceived by the ear. Therefore, the action-reaction pattern of the actors' bodily movements weakens the action-reaction pattern in their voices, when the actors deliver the dialogues prescribed by the dramatic text. The dialogue thus has an effect on the audience mainly by its semantic side (signatum), whereas its material side (signans) barely makes itself noticed. The theatregoer, then, projects the semantics of the spoken dialogic utterances onto the visible bodies. A mutual exchange takes place between the two most important sign-classes of the 'dramatic theatre': The verbal signs receive from the bodily signs a more effective sensorial basis, while the bodily signs receive from the verbal signs a more effective intellectual loading.

This conception of the relation between bodily signs and verbal signs establishes an opposition between Zich's and Aristotle's aesthetics. The philosopher, though, admits that the human being's attention is most of all attracted by visual perceptions (ARISTOTLE 1987). Yet this natural inclination changes in the experience of verbal art. Verbal signs generally attract attention much more by their intellectual side than by their audible side, because man is more a thinking than a sensory being. The uneven wages in the structure of the verbal sign (prevalence of the semantics over the sounding in the logos) must not only remain intact in verbal art, but the author should even enhance the logical side. This happens in the written drama. Therefore, the drama's main (intellectual) qualities are perfectly perceivable in the process of reading. On the Greek stage, where the actors and various art kinds like stage architecture, stage setting, dancing, singing, and instrumental music used to add to the dramatist's art, the fragile uneven balance between the two parts of the verbal signs must be held up. Aristotle particularly distrusts actors who by various vocal, mimic, and bodily manoeuvers try to attract the main share of the audience's attention onto themselves. Zich (1986: 56), on the contrary, wishes the actors' art to reign over all the other arts, yet most of all over the dramatic author. 
We can draw from Aristotle an argumentation that might make Mukařovský's critique on Zich's concept of stylization and on the formalists' concept of deformation plausible. Stylization in the way defined by Zich (1986: 299) is itself a deformation of the literary drama, because it sets the actors' art in the position of the dominant art. The other arts can actualize their own intrinsic aesthetic potentials only insofar as they serve that dominant art. Formalist deformation is, as the very term indicates, a negative, deforming principle. It lacks the counter-pole of the positive, forming principle. In his Poetics, Aristotle (1987) circumscribes the negative principle of deformation, when he discusses the poetic rules for the words and sentences in a drama. These rules serve to make the text special, unusual in comparison to the unspecial, usual forms in everyday language usage. The intention of the work's author, then, should be to create an inner tension between the unusual and the usual form, yet the deviation of the unusual form from the usual form may not destroy the latter, because in such a case the text would lose intelligibility. On the other hand, the text wins by its poetic form such qualities, which the usual form cannot provide. (In a way, Aristotle's philosophical model of the relation between spirit and body underlies also his poetic model.) What is important is that the usual and the unusual forms are not simply 'old' and 'new' forms, as the formalist theorists would say, but regulative principles. The same kind of argumentation uses Aristotle regarding the three contents parts in a drama - action, character and thought. He gives action the highest rank among the three parts, arguing that the poetic rules for building the dramatic action, which differ from action in everyday life, are much better able to give the total dramatic work a compositional form than the other two parts, although these parts own also specific beauties.

From his early thinking about poetics and aesthetics onwards, Mukařovský seems to have been an attentive reader of Aristotle. The concept of the semantic gesture, best explained in 'On Poetic Language', published in 1940, should be read together with the 1943 article 'Intentionality and Unintentionality in Art' and also with 'Aesthetic Function, Norm and Value as Social Facts', published in 1936. The earliest of these three articles from 1936 centres on the notion of value, while the two later ones from 1940 and 1943 tell something about the reasons value was displaced to the background of Mukařovský's structural aesthetic thinking.

'On Poetic Language' exposes three principles regulating the positive poetic form imposed upon the language material. In this way, the article appears to be a continuation of Aristotle's Poetics. These principles are the following:

1. Unity of meaning; this principle explains that the words, sentences and paragraphs of the poetic text are governed by the same semantic intention of the author.

2. Accumulation of meaning; this principle shows how the semantics of words, sentences and paragraphs are progressively and regressively enlarged and internally changed.

3. Oscillation between statics and dynamics of meaning; according to this principle, each entity in the text displays a stronger or weaker resistance against the all-embracing semantic unification stemming from the author's intention. 
These three principles explain why a poetic work is a structure wherein each entity fulfils a necessary function at the place determined by the poet. Aristotle calls a structure a whole, wherein any change in the number of parts and in their order causes a change, or even the destruction of the whole.

'On Poetic Language' (MUKAǨOVSKÝ 1982) lays also bare how Mukařovský understands the role of everyday language in poetics. He starts from the three functions in Karl Bühler's Organon-Model: expression, representation, and appeal. The three functions are objectively inherent in the utterance pronounced by a speaker and addressed to a hearer. In a poetic work, the three communicative functions elaborate more precisely what Aristotle calls the unspecific, usual form of language. Aristotle's specific, unusual forms reappear in the fourth, aesthetic function, which Mukařovský (1982) adds to Bühler's Organon-Model.

The aesthetic function transforms the communicative functions - also called "practical' functions - by means of the principles of the semantic gesture. The procedure of transformation has two results: (1) The total verbal text manifests itself as a background-foreground construction. The foreground-construction shows the poetically transformed, unusual text, the background-construction preserves certain elements of the forms used by the communicative functions, which guarantee the intelligibility of the total text demanded in Aristotle's Poetics. (2) The intention of the author of the poetic text is the creation of a new kind of sign, called the aesthetic sign. At least one of the manifold characteristics of the aesthetic sign mentioned by Mukařovský deserves special attention in my context: the relations of the three communicative functions with speaker, hearer, and communicated object do not transgress the border of the aesthetic sign. The Organon-Model functions only inside the aesthetic sign; it is no Mimesis of communication in the real world. This point is especially relevant in 'Aesthetic Function, Norm and Value as Social Facts' (MUKAŘOVSKÝ 1970). I will return to this point later.

In 'Intentionality and Unintentionality in Art' Mukařovský (1966) introduces 'nonsign' as a new term into his functional and semiotic aesthetic theory. The concept of the aesthetic sign, until then discussed under the pairing of aesthetic sign versus communicative (practical) sign, appears now also under the pairing of aesthetic sign versus non-sign. Mukařovský (1966) calls the non-sign a thing. The reason why he thinks it necessary to distinguish between the two natures - sign and thing - of a work of art is his concern for the material in art manifested in his critique on Zich's principle of stylization and the formalists' deformation, both of which 'devour' the verbal material. He now seems to see a similar danger in his own semiotization of the aesthetic function started already in the 1934 article 'Art as a Semiotic Fact'. According to Karl Bühler (1990), a material phenomenon like the sound of a spoken word contains much more sensory qualities than it is necessary for its perception as a sign. The recipient of the spoken word abstracts from the irrelevant surplus of qualities (paralinguistic elements) and takes account only of the relevant features. The same principle of so-called 'abstractive relevance' (German: abstractive Relevanz) works also in the perception of a work of art regarded as an aesthetic sign. Within the contrastive pair of intentionality 
and unintentionality applied to the work of art as a sign and a thing, the thing does not play the role of the passive, inert part, but of an active, though secondary counterpart. Mukařovský (1966) interprets the thing's activity as 'also a kind of intentionality'. This kind of secondary intentionality inheres in the semantic gesture as a background of its primary intentionality. It preserves the long living effectiveness of the aesthetic function of a work of art against automatization, which would turn the work into a 'practical' communicative sign. Mukařovský adopts the term intentionality as strictly distinguished from intention, from Edmund Husserl.

In 'Aesthetic Function, Norm, and Value as Social Facts' Mukařovský's concern for materiality reaches even deeper (MUKAŘOVSKÝ 1970). He discerns between four functions rooted in the anthropological constitution of the human being: the practical function that serves to maintain man's biologic organism, the cognitive function serving man's strive at cognition, the magic-religious function, by which man wishes to master the natural world and his fellowmen, and the aesthetic function. Within the ensemble of the four functions, the aesthetic function keeps a special place. Unlike the other functions, its energetic power (in the 1943 article that power is split in intentionality and unintentionality) does not aim at an outer object. It brings the autonomous, self-sufficient work of art into being.

The doctrine of autonomy and self-sufficiency, already propagated by the Russian Formalists, prepares Mukařovskýs turn to the concepts of the semantic gesture and of the work of art as a sign and a thing. Yet on his way to these concepts, he seems to lose the notion of value out of sight. The loss is important, because value is an intrinsic component especially of thought and action in a dramatic work.

The article 'Aesthetic Function, Norm, and Value as Social Facts' (MUKAǨOVSKÝ 1970) deals with the three title notions under their common aspect of 'Social Facts'. Mukařovský seems to ask himself: What is the autonomous, self-sufficient work of art good for in society? The answer is a short formula: The work of art is a 'model' of experimental reassembling of the collective value system (MUKAŘOVSKÝ 1970: 83-84). The model building force is - in art and only there - the aesthetic function, which lacking an outer object of its own, 'draws' into its specific sign-construction the objects of the three other functions as a kind of filling. As any anthropological function is an investment of energy, the object aimed at must be worth the effort. Society establishes a collective system of values that prescribes the objects the individual members can or must strive after. Mukařovský (1970: 78, footnote) names the collective value system an ideology. Societies tend to regulate also the aesthetic function by normative rules. The anthropological founding of the aesthetic function, however, sets the creative individual into the right to resist such external, ideological pressure. The aesthetic function thus appears as an emancipating potential inherent in the individual. Emancipation itself is a value in democratic societies. Therefore, it is important to examine the role of values in the drama, because in this genre the individual and the society are likewise at stake. 


\section{The deficit of the semantic gesture in structural dramatic analysis and its possible remedy by the gesture}

When I reread Jiří Veltruskýs treatise Drama as Literature (1942), which presents the best existing analysis of the semantic gesture in drama, I missed reference to Mukařovskýs experimental model of non-aesthetic social values. The model distinguishes clearly between the existence of collective values outside and inside the work of art. Inside the dramatic work, the values are correlates of the dramatic characters' thoughts and deeds expressed in the dialogues. The Greek dramatist Euripides presents examples of how the characters' thoughts and their consequent deeds refer to values.

I take my example from Euripides' famous tragedy Medea. The place is the palace of King Creon in Corinth. Jason wanting to reach a higher status in society intends to marry Creon's daughter Glauke; Creon gives his consent only if Jason divorces his wife Medea and banishes her from the land. The conflict between husband and wife results in Medea's murder of their two children and of Glauke. Medea takes the dead children with her in the dragon waggon sent by the sun god Helios. Her motive is revenge on Jason's infidelity.

The discussions between Jason and Medea manifest two opposite conceptions of justice. In the Greek society, codified laws maintained public order and peace especially in marriage. Marriage law accords the husband the right to divorce his wife and take her as a servant to his new wife. According to Jason, Medea, a princess from barbarian Colchis, should be grateful for the chance to enjoy the value of justice in civilized Greece. Medea is not at all grateful, because she knows a different conception of justice, where the law of marriage prescribes equal rights between husband and wife. These laws are evidently under the protection of the god Helios, who saves Medea from mere force, by which Creon threatens to kill Medea, because she revolted against public order and peace.

In the Greek democracy, codified laws prescribed indeed unequal rights for man and woman in marriage as well as everywhere else in society. Yet at the same time, great thinkers like Plato (in his The State/Politeia) and outstanding dramatists like Euripides interpreted justice in terms of equal rights. In Medea as well as in other tragedies of his, Euripides presents two controversial ideas about justice. According to Medea's idea of justice, the governing Greek law serves injustice. Jason and King Creon, when speaking about justice think of privileges and force which maintains privileges. So these two characters do confirm Medea's thought about the so-called 'justice' in Greek civilization. A more deep-going analysis following the semantic gesture would have to find out how the author weighs the controversial positions in the experimental model of values inherent in his play. The semantic gesture supplemented by Mukařovskýs model, would then realize Otakar Zich's wish of bringing together the aesthetics from down with the aesthetics from up, although that would not serve Zich's aesthetics of 'dramatic theatre'. 


\section{Acknowledgements}

The author is grateful to Dr. Lilia Schürcks for language advice.

\section{Bibliography}

ARISTOTLE. 1987. Poetics. Transl. by Richard Janko. Indianapolis: Hackett Publishing Company, Inc., 1987.

BÜHLER, Karl. 1990 [1934]. The Theory of Language: The Representational Function of Language (Sprachtheorie). Transl. by Donald Fraser Goodwin. London: John Benjamins, 1990.

MUKAǨOVSKÝ, Jan. 1966a. L'art comme fait sémiologique [Art as Semiotic Fact]. In id. Studie z estetiky [Studies in Aesthetics]. Prague: Odeon, 1966: 85-88.

MUKAŘOVSKÝ, Jan. 1966b. Záměrnost a nezáměrnost v umění [Intentionality and Unintentionality in Art]. In id. Studie z estetiky [Studies in Aesthetics]. Prague: Odeon, 1966: 89-108.

MUKǍ̌OVSKÝ, Jan. 1970 [1936]. Aesthetic Function, Norm and Value as Social Facts. Ann Arbor: Michigan Slavic Publications, 1970.

MUKAŘOVSKÝ, Jan. 1982 [1940]. O jazyce básnickém [On Poetic Language]. In id. Studie z poetiky [Studies in Poetics]. Prague: Odeon, 1982: 93-136.

MUKAŘOVSKÝ, Jan. 2016 [1940]. On the Current State of the Theory of Theatre. In David Drozd, Tomáš Kačer and Don Sparling (eds). Theatre Theory Reader: Prague School Writings. Prague: Karolinum, 2016: 59-75.

PATOČKA, Jan. 1991. Sókratés: přednášky z antické filosofie [Socrates: The Lectures in Ancient Philosophy]. 1. vyd. Prague: SPN, 1991.

ZICH, Otakar. 1931. Estetika dramatického umĕni [Aesthetics of the Dramatic Arts]. $1^{\text {st }}$ ed. Prague: Melantrich, 1931 (reprint Würzburg: Jalreprint, 1977).

VELTRUSKÝ, Jiří. 1999 [1942]. Drama jako básnické dílo [Drama as Literature]. Brno: Host, 1999. VELTRUSKÝ, Jiří. 2016 [1941]. Structuralism and Theatre. In David Drozd, Tomáš Kačer and Don Sparling (eds.). Theatre Theory Reader: Prague School Writings. Prague: Karolinum, 2016: $76-85$. 


\section{Professor Herta Schmid}

Institut für Slavistik, Universität Potsdam, Am Neuen Palais 10, Haus 01, D-14469 Potsdam, Germany

herta-schmid@hotmail.com

Herta Schmid is a Professor emerita at Potsdam University and a professor at universities in Bochum, Munich and Potsdam in Slavic literary studies, especially Russian, Polish, and Czech. She also taught as a professor at the Theatre Department at the University of Amsterdam. Her main fields of interest include theory of literature (Prague Structuralism, Russian Formalism, aesthetics), theory of drama, semiotics of theatre, literary analysis, and comparative studies. Her major publications include Struktury a funkce. Výbor ze studií 1989-2009 [Structures and Functions. A Selection of Studies 1989-2009] (Karolinum, 2011), Lermontov neu bewertet [Lermontov Revisited], edited by Herta Schmid and Jenny Stelleman (Verlag Otto Sagner, 2013). A recent collection of studies: Herta Schmid, Literatur als Kunst: Studien zum tschechischen Strukturalismus, edited by Birgit Krehl (Peter Lang, 2019). 